\title{
Evaluation of dahi collected from Netrokona district in Bangladesh
}

\author{
Ahmed $\mathrm{S}^{1}$, Islam $\mathrm{MN}^{2 *}$, Rashid $\mathrm{MH}^{2}$, Islam $\mathrm{MM}^{3}$, Masum $\mathrm{AKM}^{2}$ \\ ${ }^{1}$ Department of Dairy and Poultry Science, Bangabandhu Sheikh Mujibur Rahman Agricultural University, \\ Gazipur-1706, Bangladesh; ${ }^{2}$ Department of Dairy Science, Bangladesh Agricultural University, Mymensingh- \\ 2202, Bangladesh; ${ }^{3}$ Department of Animal Breeding and Genetics, Bangabandhu Sheikh Mujibur Rahman \\ Agricultural University, Gazipur-1706, Bangladesh
}

\begin{abstract}
The aim of the present research work was to make a comparative study between the quality of dahi available in Netrokona district of Bangladesh and dahi prepared in the laboratory by following standard manufacturing process. For this purpose dahi (control) was prepared in Dairy Technology Laboratory of the Department of dairy science, Bangladesh Agricultural University, Mymensingh. The Laboratory made dahi was designated as A type dahi. On the other hand four different types of dahi sample were collected from four different sweetmeat shop of Netrokona district. One sample was taken from each sweetmeat shop and three replications were made for each sample. Source of dahi samples were Khan Mistanno Vandar; Krisno Mistanno Vandar; Shankar Mistanno Vandar; Misti Mokh, These samples were designated as B, C, D and E respectively. Parameters used to monitor the quality of dahi were physical, chemical and microbiological. Collected data were compiled and statistically analyzed by using one way analysis of varience (ANOVA) test by using MSTAT statistical package. It was observed that total physical score for A, B, C, D and E type of samples were 93.21 $\pm 0.51,86.98, \pm 0.63,78.99 \pm 0.62$, $76.47 \pm 0.25$ and $83.89 \pm 0.44$ respectively. Statistical analysis showed that total score for A type (Lab. made) dahi was significantly $(p>0.01)$ higher than the total score of other dahi samples. Chemical analysis showed that average fat, protein, total solids, solids not fat, ash and lactose content of A type dahi were significantly $(p>0.01$ ) higher than that of the B, C. D and E type dahi samples collected from different shops of Netrokona district. Microbiological analysis showed that total bacterial count, yeast and mould count of $B, C, D$ and $E$ type dahi samples were also significantly $(p>0.01)$ higher than A type dahi which was prepared in the laboratory. Although total number of coliform bacteria was lower in A type sample but there was no significant difference within different dahi samples. Judging from the results of all parameters studied it was observed that dahi samples collected from Netrokona district was inferior to dahi prepared in the Laboratory. It was also observed that quality of other four dahi samples of Netrokona was nearly similar.
\end{abstract}

Key words: dahi, sweetmeat, organoleptic, coliform, tribal Bangladesh Animal Husbandry Association. All rights reserved.

Bang. J. Anim. Sci. 2016. 45 (2): 60-65

\section{Introduction}

Dahi is the curd resulting from lactic fermentation of milk. It is one of the oldest fermented milk products and is the most popular dairy food item in Bangladesh. Dahi is the simplest way of preserving milk for human consumption in a tropical condition. The lactic acid produced during fermentation checks putrefactive changes which gives it an acid type pleasant aromatic taste and is particularly refreshing in a hot climate. Fermentation imparts high therapeutic value beyond the nutritional value of milk (Oberman and Libudzisz, 1998).

*Corresponding author: mnislamds@yahoo.com
Fermented milk products are the main some of probiotic bacteria as because probiotic cultures are used for preparation of this type of products. Lactobacillus acidophilus, Lactobacillus bulgaricus, Streptococcus lactis, Streptococcus cremoris etc. are used in bacterial culture of dahi. The majority of the benefits of probiotics are seen in the digestive system. Probiotics improve the general health of the gastrointestinal tract, reduce the symptoms of lactose intolerance, help in the treatment of diarrhoea, inflammatory bowel disease, and irritable bowel syndrome, and help to prevent colon cancer. Probiotics also enhance the immune system and helps to reduce 
some allergic reactions. There is also an indication that probiotics may play a role in inhibiting Heliobacter pylori infections which cause ulcers, and in maintaining vaginal health (Santosa et al. 2006).

People who cannot digest milk due to shortage of lactase enzyme in their body, resulting in bloating, abdominal cramps, flatulence, and loose stools can digest any fermented dairy products including dahi very easily (Vesa et al., 2000; Savaiano et al. 2006). Although dahi is very popular and highly nutritious food but its quality mainly depends on manufacturing process and wholesomeness. Very little work has been done to monitor the quality of dahi available in local markets. In this experiment attempts were made to evaluate the quality of dahi prepared by different sweet meat makers of Netrokona district by comparing it with standard dahi prepared at the Dairy Technology and Microbiology Laboratory of the Department of Dairy Science, Bangladesh Agricultural University.

\section{Materials and methods}

The experiment was conducted at the Dairy Technology and Microbiology Laboratory of the Department of Dairy Science, Bangladesh Agricultural University, Mymensingh for a period of 3 months, starting from 10 September to 10 December 2013.

\section{Collection of dahi samples}

Four different sweetmeat shops from Netrokona district were selected for experimental purpose. During the study period dahi samples from each shop was collected three times and there were a total of 12 samples from Netrokona. Dahi samples were brought to the Laboratory with the help of ice boxes, maintaining at the temperature of around $4^{\circ} \mathrm{C}$. There after collected samples were stored in refrigerator at $4^{\circ} \mathrm{C}$ until analysis. Simultaneously dahi was prepared in the Dairy Technology Laboratory of the Department of Dairy Science of Bangladesh Agricultural University during the same period. Dahi prepared in the laboratory was treated as control sample. So, a total of 13 dahi samples were involved in this study. The layout of the experiment is shown in Table 1.
Table 1. Sources of dahi from different areas

\begin{tabular}{clc}
\hline Serial. No & \multicolumn{1}{c}{ Source of dahi sample } & Designation \\
\hline 1 & $\begin{array}{l}\text { Dahi prepared in the Laboratory } \\
\text { (control) }\end{array}$ & A \\
2 & $\begin{array}{l}\text { Khan Mistanno Vandar, Kurpar, } \\
\text { Netrokona } \\
\text { Krisno Mistanno Vandar, } \\
\text { Durgapur, Netrokona } \\
\text { Shankar Mistanno Vandar, } \\
\text { Mohongonj, Netrokona }\end{array}$ & B \\
4 & D \\
5 & Misti Mokh, Kendua, Netrokona & E \\
\hline
\end{tabular}

\section{Analysis of the samples}

All dahi samples were subjected to physical, chemical and microbiological analysis to evaluate their quality.

\section{a) Physical tests (Sensory and organoleptic evaluation) \\ - Smell and taste ( 50 marks) \\ - Body and consistency (30 Marks) \\ - Colour and appearance (20 marks)}

All the experimental samples were organoleptically evaluated by an expert panel of judges using a score card.

\section{b) Chemical tests}

- Acidity percentage

- Determination of $\mathrm{P}^{\mathrm{H}}$

- Fat content $(\mathrm{g} / \mathrm{kg})$

- Protein content $(\mathrm{g} / \mathrm{kg})$

- Total solids (TS) content $(\mathrm{g} / \mathrm{kg})$

- Ash content $(\mathrm{g} / \mathrm{kg})$

Fat and protein content of dahi sanples were determined by Babcock method and Kjeldahl method respectively as per procedure described by Aggarwala and Sharma (1961). Total solids, ash and acidity of dahi samples were determined by using procedure described in A.O.A.C. (2003). $\mathrm{pH}$ value was measured with the help of $\mathrm{pH}$ meter-215 (Ciba coming Diagnostics Ltd. Sudbury, Suffolk, England Co. 106xD).

\section{c) Microbiological tests}

- Total viable count (cfu/ml)

- Coliform count (cfu/ml)

- Yeast and mould count (cfu/ml)

All microbiological tests were conducted as per procedure described in the "Standard Methods for the Examination of Dairy Products" American Public Health Association (APHA, 2004). 


\section{Statistical analysis}

Analysis of variance (ANOVA) test was done by Completely Randomized Design, using MSTAT statistical package. In case of significant difference the treatment means were ranked by Duncan's Multiple Range Test (DMRT) (Gomez and Gomez, 1984).

\section{Results and Discussion}

The results of study for various organoleptic parameters, chemical composition and microbiological status of different types of dahi are presented in this section.

\section{Physical Parameters}

\section{Smell and Taste}

The average smell and taste scores for sample $A$ was $47.00 \pm 0.82$, for $B$ was $44.43 \pm 0.26$, for $C$ was $41.67 \pm 0.10$, for $D$ was $40.77 \pm 0.19$ and for $E$ was $43.40 \pm 0.10$ (Table 2). Statistical analysis showed that there was significant difference among those treatments. Smell taste score for A type ( laboratory made) dahi was significantly higher than that of other samples collected from Netrokona indicating that Laboratory made dahi was better than market dahi.The result of this study agreed with the findings of Younus et al., (1998) who found that the laboratory prepared dahi was better than dahi collected from Mymensingh city. The result of this experiment also agreed with the findings of Rahman (2010) who reported that smell and taste score of Laboratory prepared dahi was slightly higher than that of the collected from local market.

\section{Body and Consistency}

Table 2. Physical parameters of dahi collected from different sweetmeat shops

\begin{tabular}{|c|c|c|c|c|c|c|}
\hline \multirow{2}{*}{$\begin{array}{l}\text { Parameters } \\
\text { measured }\end{array}$} & \multicolumn{5}{|c|}{ Types of dahi } & \multirow[t]{2}{*}{ Significance } \\
\hline & A & B & C & D & E & \\
\hline Smell \& Taste & $47.00^{\mathrm{a}} \pm 0.82$ & $44.43^{b} \pm 0.26$ & $41.67 \pm 0.10$ & $40.77^{\mathrm{d}} \pm 0.19$ & $43.40 \mathrm{e} \pm 0.10$ & ** \\
\hline Body \& Consistency & $28.30^{\mathrm{a}} \pm 0.33$ & $26.41^{b} \pm 0.31$ & $23.48^{c} \pm 0.05$ & $21.28 \mathrm{~d} \pm 0.05$ & $25.52^{\mathrm{e}} \pm 0.59$ & ** \\
\hline Color \& Appearance & $17.91^{a} \pm 0.06$ & $16.14^{b} \pm 0.35$ & $13.84^{c} \pm 0.61$ & $14.42^{\mathrm{cd}} \pm 0.46$ & $14.96^{d} \pm 0.25$ & ** \\
\hline Total & $93.21^{\mathrm{a}} \pm 0.51$ & $86.98^{b} \pm 0.63$ & $78.99 c \pm 0.62$ & $76.47^{\mathrm{d}} \pm 0.25$ & $83.89 \mathrm{e} \pm 0.44$ & ** \\
\hline
\end{tabular}

Different letters indicate A, dahi prepared in the Laboratory (control); B, Khan Mistanno Vandar, Kurpar, Netrokona; C, Krisno Mistanno Vandar, Durgapur, Netrokona; D, Shankar Mistanno Vandar, Mohongonj, Netrokona; E, Misti Mokh, Kendua, Netrokona. Similar superscripts in the same row does not differ significantly, ${ }^{* *}$, significant at $1 \%$ level.
The mean body and consistency scores for A was $28.30 \pm 0.33$, for $B$ was $26.41 \pm 0.31$, for $C$ was $23.48 \pm 0.05$, for $D$ was $21.28 \pm 0.05$ and for $E$ was $25.52 \pm 0.59$. Statistical analysis showed that there was significant difference within the body and consistency score of different dahi samples. The mean value of body and consistency was highest for Lab prepared dahi. The variation in body and consistency scores among different samples might be due to different types of starter culture used and manufacturing processes employed by various manufactures. Regarding this Pette and Lolkema (1952) pointed out that heat treatment of milk from $80^{\circ} \mathrm{C}$ to $90^{\circ} \mathrm{C}$ for 10 minutes could bring firm consistency in dahi. The result of this study also agreed with the findings of Younus et al. (1989) and Rahman (2010).

\section{Colour and appearance}

The mean color and appearance scores for $A$ was $17.91 \pm 0.06$, for $B$ was $16.14 \pm 0.35$, for $C$ was $13.84 \pm 0.61$, for $D$ was $14.42 \pm 0.46$, and for $E$ was $14.96 \pm 0.25$ (Table 2). Significant difference was found among those mean values in respect of colour and appearance. The result of colour and appearance of the present study agrees with the result of Younus (1998) who found that the colour and appearance score of dahi collected from different sweetmeat shops was lower than that of the score of laboratory made dahi. In this aspects Yesmin (2013) observed that fat level in dahi can influenced the colour and appearance score. In this experiment fat content of A type (Laboratory made) dahi was higher than other dahi samples which might be the cause of high colour and appearance in Labpratory made dahi. 


\section{Chemical Parameters}

\section{Acidity}

The mean acidity value (\%) for A type dahi was $0.63 \pm 0.02$, for $B$ was $0.72 \pm 0.01$, for $C$ type was $0.78 \pm 0.01$, for $D$ type was $0.81 \pm 0.01$ and for $E$ was $0.74 \pm 0.01$ (Table 3 ). Statistical analysis showed that there were significant $(p>0.01)$ differences among the samples. The result of acidity content of different types of dahi agrees with the findings of Chowdhury ( 2014) found that acidity content of dahi collcted from Dhaka city ranged from 0.70 to 0.90 per cent which is similar to the result of present experiment.

\section{pH}

The mean $\mathrm{pH}$ value of $\mathrm{A}, \mathrm{B}, \mathrm{C}, \mathrm{D}$ and $\mathrm{E}$ type of dahi samples were $4.89 \pm 0.07,4.68 \pm 0.04$, $4.32 \pm 0.10,4.18 \pm 0.04$ and $4.44 \pm 0.11$ respectively ( Table 3 ). Statistical analysis showed that there were significant differences among the samples. This might be due to the fact that the culture used in market dahi samples were inferior in quality than the culture used in the laboratory made dahi. Generally high acidic culture decreases the $\mathrm{pH}$ content of fermented dairy products. The results of the present findings agreed with the work of Mustafa and Frank (1991) who found that $\mathrm{pH}$ of dahi was around 4.25. Similar type of $\mathrm{pH}$ value was also reported by Yesmin (2013) and Chowdhury (2014).

\section{Fat}

The mean fat $(\mathrm{g} / \mathrm{kg})$ of dahi $A$ was $45.50 \pm 1.32$, for $B$ was $37.17 \pm 1.04$, for $C$ was $27.67 \pm 2.31$, for $D$ was $29.00 \pm 0.00$ and for $E$ was $35.00 \pm 0.00$.. Statistical analysis showed that there were significant differences among the samples.
Highest fat content were seen in sample $A$ and lowest was in the sample $C$. This result indicates that Laboratory dahi was prepared by using high quality whole milk. On the other hand partially skimmed milk might have been used in market milk dahi. This result also agreed with the work of Younus (1998) and Chowdhury (2014).

\section{Protein}

The mean protein value $(\mathrm{g} / \mathrm{kg})$ of $A, B, C, D$ and $E$ types of dahi were $41.97 \pm 0.45,38.13 \pm 0.15$, $32.33 \pm 0.29, \quad 35.23 \pm 0.49$ and $36.63 \pm 0.76$, respectively (Table 3 ). Statistical analysis showed that there were significant differences within the samples. The highest protein content was seen in the samples $A$ and the lowest was seen in sample C. High protein in A type dahi indicates that milk used in Laboratory made dahi was better than that of the milk used in market dahi preparation. The results of the present study agreed with the findings of Desai et al. (1994). Yesmin (2013) mentioned that quality of milk used in dahi preparation reflects its chemical composition.

\section{Total Solids}

The mean Total Solids content $(\mathrm{g} / \mathrm{kg})$ of $A, B, C$, $D$ and $E$ types of dahi were $225.47 \pm 18.95$, $188.53 \pm 6.06,176.27 \pm 2.68,166.17 \pm 2.40$ and $176.23 \pm 0.23$ respectively (Table 3 ). There were significant differences among the total solids content of different types of dahi. Total solid content was highest in sample $A$ and lowest in sample $D$. This might be due to high total solids content of milk used for preparation of $A$ type dahi.

Table 3. Chemical parameters of dahi collected from different sweetmeat shops

\begin{tabular}{|c|c|c|c|c|c|c|}
\hline \multirow{2}{*}{$\begin{array}{l}\text { Parameters } \\
\text { measured }\end{array}$} & \multicolumn{5}{|c|}{ Types of dahi } & \multirow{2}{*}{$\begin{array}{c}\text { Signific } \\
\text { ance }\end{array}$} \\
\hline & A & B & C & D & E & \\
\hline Acidity \% & $0.63^{e} \pm 0.02$ & $0.72^{\mathrm{d}} \pm 0.01$ & $0.78^{b} \pm 0.01$ & $0.81^{a} \pm 0.01$ & $0.74^{c} \pm 0.01$ & $* *$ \\
\hline $\mathrm{pH}$ & $4.89^{a} \pm 0.07$ & $4.68^{b} \pm 0.04$ & $4.32^{c} \pm 0.10$ & $4.18^{d} \pm 0.04$ & $4.44^{c} \pm 0.11$ & ** \\
\hline Fat $(\mathrm{g} / \mathrm{kg})$ & $45.50^{\mathrm{a}} \pm 1.32$ & $37.17^{\mathrm{b}} \pm 1.04$ & $27.67^{c} \pm 2.31$ & $29.00^{c} \pm 0.00$ & $35.00^{b} \pm 0.00$ & ** \\
\hline Protein $(\mathrm{g} / \mathrm{kg})$ & $41.97 a \pm 0.45$ & $38.13^{b} \pm 0.15$ & $32.33^{\mathrm{e}} \pm 0.29$ & $35.23^{\mathrm{d}} \pm 0.49$ & $36.63^{c} \pm 0.76$ & ** \\
\hline Total solids ( $/ \mathrm{kg}$ ) & $225.47^{\mathrm{a}} \pm 18.95$ & $188.53^{b} \pm 6.06$ & $176.27^{\mathrm{bc}} \pm 2.68$ & $166.17^{\mathrm{c}} \pm 2.40$ & $176.23^{b c} \pm 0.23$ & ** \\
\hline Ash \% & $8.47^{a} \pm 0.35$ & $6.53^{b} \pm 0.06$ & $5.20^{\mathrm{d}} \pm 0.17$ & $4.50^{\mathrm{e}} \pm 0.26$ & $5.97^{c} \pm 0.23$ & ** \\
\hline
\end{tabular}

Different letters indicate A, dahi prepared in the Laboratory (control); B, Khan Mistanno Vandar, Kurpar, Netrokona; C, Krisno Mistanno Vandar, Durgapur, Netrokona; D, Shankar Mistanno Vandar, Mohongonj, Netrokona; E, Misti Mokh, Kendua, Netrokona. Similar superscripts in the same row does not differ significantly, ${ }^{* *}$, significant at $1 \%$ level. 
At the same time manufacturing technology e.g. heat treatment and sugar level might have affected the total solids content of different dahi samples. Sarker et al. (1996) reported that average total solids content of dahi collected from different districts of West Bengal was on an average of 40.27 per cent. Ghosh and Rajorhia (1987) stated that total solids content of plane market dahi varied from 26.92 to 43.04 per cent with an average value of 34.64 per cent. The result of total solids content of dahi samples of this experiment agreed with the findings of Younus (1998).

\section{Ash}

The mean ash value of $A, B, C, D$ and $E$ types of dahi were $8.47 \pm 0.35,6.53 \pm 0.06,5.20 \pm 0.17$, $4.50 \pm 0.26$ and $5.97 \pm 0.23$ respectively (Table 3 ). Highly significant differences were found among those mean values. The result of the ash content agrees with the work of Younus (1998).

\section{Microbiological parameters}

\section{Total Viable Organism Count}

Table 4 reported he mean total bacteria per $\mathrm{ml}$ for A type dahi was $14.00 \times 10^{4} \pm 2.65 \times 10^{4}$, for $B$ type was $17.00 \times 10^{4} \pm 1.73 \times 10^{4}$, for $C$ type was $35.00 \times 10^{4} \pm 3.46 \times 10^{4}$, for $D$ type was $42.00 \times 10^{4} \pm 1.73 \times 10^{4}$ and for $E$ type was $24.67 \times 10^{4} \pm 0.58 \times 10^{4} \mathrm{cfu} / \mathrm{ml}$, respectively Results indicated that there were significant variations in average total viable counts. Highest bacterial count was in sample D type dahi sample which might be due to more favorable condition for growth of microbes. The result of these parameters agreed with the result of Adeyl (1998).

\section{Coliform count}

Average coliform bacteria per $\mathrm{ml}$ of $\mathrm{A}, \mathrm{B}, \mathrm{C}, \mathrm{D}$ and $E$ types of dahi were $5.33 \pm 2.08,6.33 \pm 2.3$, $6.33 \pm 1.15,9.00 \pm 0.00$ and $6.67 \pm 0.58 \mathrm{cfu} / \mathrm{ml}$ respectively (Table 4 ). Results indicated that there were no significant variations in average coliform count among the samples. The results of these parameters agreed with that of the results of Ghosh and Rajorhia (1987).

\section{Yeast and Mould Count}

Average yeast count per $\mathrm{ml}$ of $\mathrm{A}, \mathrm{B}, \mathrm{C}, \mathrm{D}$ and $\mathrm{E}$ types of dahi were $18.00 \pm 3.00,18.67 \pm 3.51$, $30.33 \pm 0.58,29.67 \pm 2.89$, and $23.67 \pm 1.15 \mathrm{cfu} / \mathrm{ml}$ respectively (Table 4 ). On the other hand, the average mould count per $\mathrm{ml}$ of $\mathrm{A}, \mathrm{B}, \mathrm{D}$ and $\mathrm{E}$ types of dahi were $17.33 \pm 1.15,21.67 \pm 0.58$, $27.67 \pm 2.31,31.00 \pm 3.46$ and $23.67 \pm 1.15 \mathrm{cfu} / \mathrm{ml}$ respectively (Table 4 ). The results in the present investigation did not exceed the range of yeast and mould counts that should be present in as reported for Sweet dahi by Adeyl (1998). From the above discussion it is clear that dahi prepared in Dairy Technology and Microbiology Laboratory of the Department of Dairy science of Bangladesh Agricultural University was superior to dahi collected from different sweetmeat shops of Netrokona District of Bangladesh. Analysis shows that quality of dahi prepared in Khan Mistanno Vandar of Netrokona (sample B) was closed to laboratory prepared dahi (sample A). The quality of other three samples of Netrokona e.g. C, D and $\mathrm{E}$ were nearly similar.

Table 4. Microbiological parameters of dahi collected from different sweetmeat shops

\begin{tabular}{|c|c|c|c|c|c|c|}
\hline \multirow{2}{*}{$\begin{array}{l}\text { Parameters } \\
\text { measured }\end{array}$} & \multicolumn{5}{|c|}{ Types of dahi } & \multirow[t]{2}{*}{ Significance } \\
\hline & A & B & C & D & $\mathrm{E}$ & \\
\hline \multirow{2}{*}{$\begin{array}{l}\text { Total } \\
\text { bacteria/ml }\end{array}$} & \multirow{2}{*}{$\begin{array}{l}14.00 \times 10^{4 d} \pm \\
2.65 \times 10^{4}\end{array}$} & $17.00 \times 10^{4 d} \pm$ & $35.00 \times 10^{b} \pm$ & $42.00 \times 10^{4 a} \pm$ & $24.67 \times 10^{4 c} \pm$ & ** \\
\hline & & $1.73 \times 10^{4}$ & $3.46 \times 10^{4}$ & $1.73 \times 10^{4}$ & $0.58 \times 10^{4}$ & \\
\hline \multirow[t]{2}{*}{$\begin{array}{l}\text { No. of } \\
\text { coliform/ml }\end{array}$} & \multirow[t]{2}{*}{$5.33^{a} \pm 2.08$} & $6.33^{\mathrm{a}} \pm 2.31$ & $6.33^{a} \pm 1.15$ & $9.00^{\mathrm{a}} \pm 0.00$ & $6.67^{a} \pm 0.58$ & NS \\
\hline & & $18.67^{c} \pm 3.51$ & $30.33^{a} \pm 0.58$ & $29.67^{a} \pm 2.89$ & $23.67^{b} \pm 1.15$ & $* *$ \\
\hline Yeast/ml & $18.00^{\circ} \pm 3.00$ & & & & & \\
\hline Mould/ml & $17.33^{c} \pm 1.15$ & $21.67^{b} \pm 0.58$ & $27.67^{a} \pm 2.31$ & $31.00^{\mathrm{a}} \pm 3.46$ & $23.67^{b} \pm 1.15$ & ** \\
\hline
\end{tabular}

Different letters indicate A, dahi prepared in the Laboratory (control); B, Khan Mistanno Vandar, Kurpar, Netrokona; C, Krisno Mistanno Vandar, Durgapur, Netrokona; D, Shankar Mistanno Vandar, Mohongonj, Netrokona; E, Misti Mokh, Kendua, Netrokona. Similar superscripts in the same row does not differ significantly, ${ }^{* *}$, significant at $1 \%$ level. 


\section{Conclusion}

The study revealed that the quality of dahi collected from different sweetmeat shops of Netrokona district of Bangladesh was inferior to the quality of dahi prepared in Dairy Technology

\section{References}

Adeyl FM (1998). Studies on the physical, chemical and microbiological qualities of misti dahi of different districts of Bangladesh. M.S. Thesis, Department of Dairy Science. Bangladesh Agricultural University, Mymensingh-2202, Bangladesh.

Aggarwala AC, Sharma RM (1961). A Laboratory Manual of Milk Inspection. Bombay, Calcutta, New Delhi, India.

AOAC (2003). Official Methods of Analysis. Association of Official Analytical Chemists, Washington DC, USA.

APHA (2004). Standard methods for the examination of dairy products. 17th edition, 8001 street, Washington DC 20001, USA.

Chowdhury MZA (2014). Quality evaluation of dahi available in Dhaka city. MS Thesis, Department of Dairy Science, Bangladesh Agricultural University, Mymensingh, December-2014.

Desai SR, Toro VA, Joshi SV (1994). Utilization of different fruits in the manufacture of yoghurt. Indian Journal of Dairy Science 47: 870-874.

Ghosh J, Rajorhia GS (1987). Chemical, microbiological and sensory properties of misti dahi sold in Kolkata. Asian Journal of Dairy Research 6: 11-16.

Ghosh J, Rajorihia GS (1987). Technology for production of misti dahi a traditional fermented milk product. Indian Journal of Dairy Science 43: 239-246.

Gomez AK, Gomez AA (1984). Statistical Procedures for Agricultural Research. Second Edition, Jhon Willey and Sons. New York pp. 95109.

Mustafa G, Frank JF (1991). Physical properties of yogurt made form milk fretted proteolytic enzymes. Journal of Dairy Science 74: 5-9.
Laboratory of the Department of Dairy Science of Bangladesh Agricultural University, Mymensingh. This difference was mainly due to the differences in manufacturing technology and better quality starter used for the preparation of dahi in the laboratory.

Oberman H, Libudzisz Z (1998). Physiological activity of Str. diacetilactis and Lb. cazci strains in continuous culture system, 201215. Microbiology of Fermented Foods, J.B. Wood Blackic Academic and Professional, Madras.

Pette JW, Lolkema H (1952). The preparation of yoghurt. Dairy Science Abstr. 14: 519.

Rahman MF, Islam MN, Hasan MN, Siddiki MSR, Naznin F (2010). Comparison of the rossogolla (Balish) prepared in the laboratory and collected from market of Netrokona District. Bang. J. Anim. Sci, 39:134-143.

Rakhi TA, Islam MN, Hoque SAM, Rahman MM (2013). Development of mango flavored soy Dahi. Bangladesh Journal of Animal science 42: 44-48.

Santosa S, Farnworth E, Jones PJH (2006). Probiotics and their potential health claims. Nutrition Reviews 64: 265-274.

Sarker S, Kuila RK, Misra AK (1996). Organoleptical, microbiological and chemical quality of mistl dahi sold in different districts of West Bengal. Indian Journal of Dairy Science 49: 54-61.

Savaiano DA, Boushey CJ, McCabe GP (2006). Lactose intolerance symptoms assessed by meta-analysis: A grain of truth that leads to exaggeration. J. Nutr. 136: 1107-1113.

Vesa T, Marteau HP, Korpela R (2000). Lactose intolerance. J. Am. Coll. Nutr. 19: 165S175 S.

Yesmin M (2013). Determination of approximate fat in milk for the production of good quality dahi. MS Thesis, Department of Dairy Science, Bangladesh Agricultural University, Mymensingh, December-2013.

Younus M (1998). A comparative study on the quality of dahi (yogurt) available in Mymensingh town. M.S. Thesis, Department of Dairy Science, Bangladesh Agricultural University, Mymensingh. 